\title{
Solution geochemistry and behaviour of major and trace elements during summer in a moss community at Edmonson Point, Victoria Land, Antarctica
}

\author{
R. BARGAGLI', R.I.L. SMITH'², L. MARTELLA', F. MONACl', J.C. SANCHEZ-HERNANDEZ' \\ and F.C. UGOLINI ${ }^{3}$ \\ ${ }^{1}$ Dipartimento di Biologia Ambientale, Università di Siena, Via delle Cerchia 3, 53 I00 Siena, Italy \\ ${ }_{2}^{2}$ British Antarctic Survey, Natural Environment Research Council, High Cross, Madingley Road, Cambridge CB3 OET, UK \\ ${ }^{3}$ Dipartimento Scienza del Suolo e Nutrizione della Pianta, Università di Firenze, Piazza Cascine 16, 50144 Firenze, Italy
}

\begin{abstract}
Physical and chemical characteristics and solution geochemistry of major and trace elements were investigated in an area of volcanic soil colonized by mosses at Edmonson Point (central Victoria Land) during the international BIOTAS (Biological Investigations of Terrestrial Antarctic Systems) expedition (BIOTEX) in the 1995-96 summer. The broad objective was to study the environmental factors involved in plant colonisation and survival in terrestrial continental Antarctic ecosystems. The results showed that moss distribution and survival throughout the summer was closely dependent on water supply. In Antarctic coastal ecosystems the environmental biogeochemistry is largely dominated by ions of marine origin. At the drier end of a hydrological gradient the dry cushions of Hennediella heimii were encrusted with salts and showed much higher concentrations of soluble ions $\left(\mathrm{Na}^{+}, \mathrm{Cl} ; \mathrm{K}^{+}, \mathrm{Ca}^{2+}, \mathrm{Mg}^{2+}, \mathrm{SO}_{4}{ }^{2-}, \mathrm{NO}_{3}^{-}\right)$than those in adhering soil particles or in other moss species from wetter parts of the transect. Although salt encrustations may partly derive from sublimation of surface snow, comparisons between concentrations of soluble ions in the dry moss and those in the $<2 \mathrm{~mm}$ fraction of surface and deep soil showed an upward migration along the soil profile of soluble ions as the substratum dried out, between December and January, and their accumulation mostly on mosses. At the wet end of the transect mosses were less affected by salt encrustations and there was evidence of $\mathrm{Ca}^{2+}$ uptake and an active cycling of nutrients.
\end{abstract}

Received 24 November 1997, accepted 16 November 1998

Key words: Edmonson Point, major and trace elements, moss community, solution geochemistry, Victoria Land

\section{Introduction}

Colonization and survival processes in Antarctic terrestrial ecosystems are dependent on a suite of favourable environmental criteria, notably moisture availability, substratum stability and adequate shelter from winds, as well as continuous periods above specific temperature thresholds (Cameron et al. 1970, Ugolini 1977, Smith 1984). The balance of these is likely to alter as the effects of climate change intensify, for example, increasing temperature, moisture and ultraviolet-B radiation. Little is yet known how terrestrial organisms respond to such changes, but a better understanding of eco-physiological processes is necessary to predict how key species may be affected by the changing environment and how community composition and dynamics may change. Furthermore, although Antarctica is isolated from other Southern Hemisphere land masses, propagules are continually being deposited (Kappen \& Straka 1988, Smith 1991, Linskens et al. 1993, Marshall 1996, Convey \& Marshall 1997) and, if suitably pre-adapted to the local conditions, may have the potential to become established. Thus, moist unstable habitats may be colonized by moss species with an ephemeral life strategy, producing vegetative propagules capable of rapid development in early summer and the establishment of shortlived communities. In stable habitats, such as moist sheltered valley floors, depressions and seepage areas, colonizing mosses tend to have a persistent life strategy capable of surviving many years and developing communities which accumulate a shallow peat.

Under the dry and high insolation regime of continental Antarctica, sublimation of snow and evaporation of water cause widespread salt encrustation in terrestrial ecosystems, not only on the rock and soil but also on the cryptogamic vegetation. The composition and distribution of superficial salts, the origin of solutes and the geochemistry of major ions in Antarctic water bodies have been the subject of numerous studies (Ugolini \& Anderson 1973, Claridge \& Campbell 1977, Green etal. 1988, De Mora etal. 1991, Gore etal. 1996, Claridge et al. 1997). However, none has related the possible effects of surface accumulation of soluble salts or the origin and availability of essential elements to the vegetation occupying sites where this phenomenon occurs.

The study of colonisation processes and ecological interactions between Antarctic organisms and their environment has been one of the main objectives of the SCAR 
(Scientific Committee on Antarctic Research) BIOTAS (Biological Investigations of Terrestrial Antarctic Systems) Program (Smith \& Wynn-Williams 1992). BIOTEX was an international expedition organized by BIOTAS, hosted by the Italian Antarctic Programme and undertaken at Edmonson Point, central VictoriaLand (December 1995-February 1996). The aim of the present study was to examine the biogeochemistry in a moss/soil system, to assess the relationship between the distribution and performance of the vegetation and the dynamics of the edaphic environment. This was achieved by analysing the elemental composition and concentrations of soluble ions in mosses, soil surface and subsurface horizons along a moisture-vegetation gradient early and late in the 1995-96 summer.

\section{Study area}

Edmonson Point $\left(74^{\circ} 20^{\prime} \mathrm{S}, 165^{\circ} 08^{\prime} \mathrm{E}\right)$ is a spur of Mount Melbourne $(2732 \mathrm{~m})$, a dormant volcano showing evidence of very recent volcanic activity (Kyle 1990). On its eastern slope is an unnamed glacier which extends to Wood Bay and onto the ice-free area of Edmonson Point (Fig. 1). This area covers about $6 \mathrm{~km}^{2}$ and is characterized by several hills (up to about $300 \mathrm{~m}$ high), knolls and moraines separated by small valleys with some small lakes, ponds and melt streams. Owing to an abundance of melt water, and marine- and bird-derived nutrients, Edmonson Point has a range of terrestrial communities. The biological structure and distribution of species in these varies along moisture and/or nutrient gradients.
The ground surface is composed mainly of dry coarsetextured volcanic materials (scoria, pumice, tuff, lava, etc.). These exposed surfaces, as well as beneath the surfaces of stones and boulders and also the upper portions of moss colonies are coated with white encrustations or efflorescences of soluble salts. Most of the ground is dark-coloured with brownish or yellowish patches of scoria and tuffite. The hill slopes are unstable, very dry and unvegetated. The floors of broad valleys and wide basins are covered by fine scoria and coarse sand and are often criss-crossed by prominent thermal contraction cracks, caused by the underlying permafrost and/ or pingos. At the beginning of summer the melting of snow reveals small stands of algae and mosses, although much of these is often largely buried by up to $5 \mathrm{~cm}$ of wind-blown and melt-washed fine mineral particles. During the early summer when moisture is available, and soil temperatures are quite high, this subpsammic community is capable of rapid growth which brings the bright green shoot apices to the surface and, for a brief time, up to a centimetre above it as the surface accumulation of sand is washed or blown away. Single events of "flash floods" or strong winds can quickly bury these stands, although growth can continue as sufficient light can penetrate $1-2 \mathrm{~cm}$ below the surface.

The principal moss communities occur in more stable environments which are not subjected to burial by sand. These are mainly in sheltered depressions or along the margins of ponds and melt water streams, and seepage areas below late snow beds where moisture is available for several weeks. These "climax" communities are among the most complex in

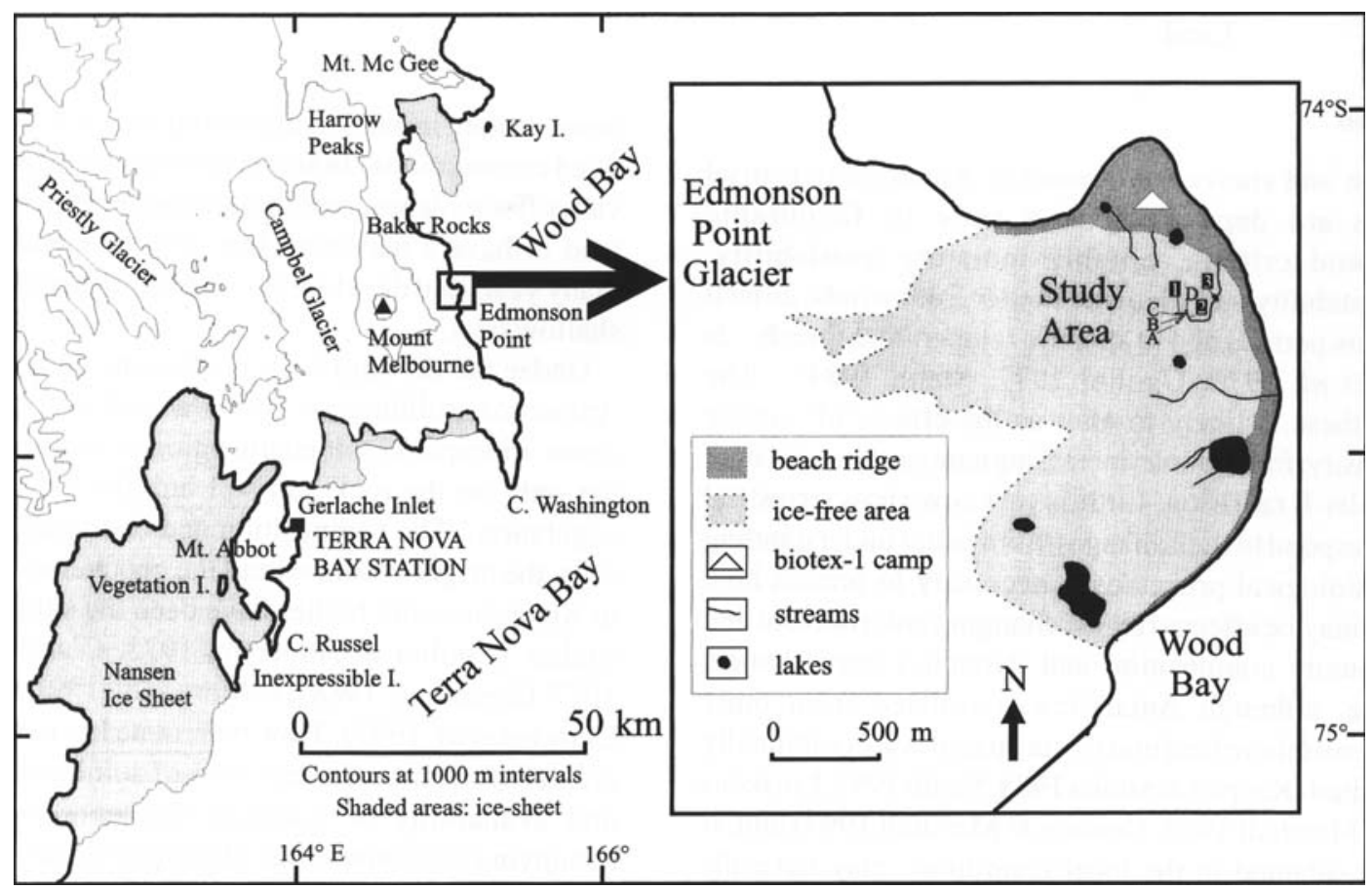

Fig. 1. Map indicating the study area and the sampling subsites of mosses and soils (A, B, C, D) and snow, stream- and pond-water $(1,2,3$, respectively). 
continental Antarctica, sometimes having up to six bryophyte species (including the liverwort Cephaloziella exiliflora (Tayl.) Steph.), several filamentous and foliose algae and cyanobacteria and, at the drier end of the moisture gradient, several lichens encrusting moribund moss. Here, also, there is a relatively diverse invertebrate fauna.

The study area was established in a moss community in a small valley about $0.5 \mathrm{~km}$ from the BIOTEX camp (Fig. 1). Here, a Campbell microclimate station operated from 11 December 1995 to 5 February 1996, recording, at $1 \mathrm{~min}$ intervals, surface and subsurface temperature at various positions within the site, and air temperature $0.5 \mathrm{~m}$ above the ground; several other parameters were also recorded. The study site had a northerly aspect, was sheltered from wind by surrounding low ridges and knolls, and received melt water from late-lying snow patches that remained on the southeastern slopes until the end of December. A small stream flowed through the site, and about $150 \mathrm{~m}$ beyond this it fed a shallow pond at the end of the valley (Fig. 1). The crest of the low ridges and knolls on either side of the valley were dry, unstable and unvegetated. Small colonies of the moss Hennediella heimii (Hedw.) Zand. grew among the dry gravel towards the centre of the valley, but the wetter central depression had a well-developed mixed moss community of Bryum argenteum Hedw., B. pseudotriquetrum (Hedw.) Gaertn., Meyer \& Scherb. and Ceratodon purpureus (Hedw.) Brid., with associated cyanobacteria (mainly Nostoc spp. and Phormidium spp.) and some crustose lichens. An account of the ecological characteristics of these mosses at this and another site at Edmonson Point is given by Smith (in press).

\section{Methods and materia!s}

\section{Sample collection}

On 23 December four samples of water (as snow, stream- or pond-water) were collected at each of three positions along the valley (Fig. 1; points 1,2 and 3, respectively). At position 2 , soils or moss were sampled along a moisture gradient transect in the central area of the main moss stand. Samples were taken at about $4 \mathrm{~m}$ intervals extending from the dry ahumic outer zone, through the thin moss covered protoranker (Fig. 1; A, B, C and D). Subsite A was very dry, not subject to liquid water either by direct flow or by capillary action, and supported no vegetation. About $60 \%$ of the area of subsite B was occupied by very short cushions or short turves of Hennediella heimii with scattered Bryum pseudotriquetrum and Ceratodon purpureus (dry and encrusted by salts). Subsite $C$ had $90-95 \%$ cover of the mixed moss community (B. argenteum, B. pseudotriquetrum, C. purpureus, C. exiliflora), with encrusting black cyanobacteria. Subsite D was located in the wet central zone, close to the small ephemeral stream where the moss (B. argenteum and $B$. pseudotriquetrum), foliose thalli of Nostoc commune and filamentous thalli of Phormidium cf. frigidum were immersed in water until 20 January.

A soil profile about $30 \mathrm{~cm}$ depth was excavated at each subsite and two samples were obtained in the active layer, one from the surface to $5 \mathrm{~cm}$ depth, the other from $5 \mathrm{~cm}$ to the surface of the ice-cemented frozen soil $(25-30 \mathrm{~cm}$ depth). The sampling procedure was repeated on 23 January, although no snow or running water samples were possible because these sources had disappeared by the end of December.

\section{Analytical determinations}

Temperature, $\mathrm{pH}$ and conductivity of stream and pond water were measured at the time of sample collection $(n=5$ for all parameters). Water samples were placed in polythene bottles previously rinsed with deionized water and washed with the sample prior to filling. $\mathrm{pH}$ was measured with an automatic temperature correcting probe, and the instrument was calibrated on a regular basis with reference buffers. For electrical conductivity (EC) measurements the recommended calibration cell constant and manual temperature corrections were used. The meters were allowed to stabilize for at least $5 \mathrm{~min}$ before a reading was taken. Total organic carbon (TOC) and total $\mathrm{N}$ contents were determined in soil samples by a modified Walkley-Black titration method (Gaudette et al. 1974) and by the Kjeldhal method, respectively.

At the BIOTEX camp subsamples of snow, water, moss and soil were stored at $-20^{\circ} \mathrm{C}$ for transport to Italy. Subsamples (about $100 \mathrm{~g}$ ) of protoranker and ahumic soil were dried in an oven to a constant weight to determine the water content. The $<2 \mathrm{~mm}$ fraction was used in the laboratory tent to perform the following analyses: particle size of the sand fraction by dry sieving (mesh sizes: 63, 125, 250, 500,1000 $\mu \mathrm{m}$ ), $\mathrm{pH}$ (on a 1:2 soil-deionized water suspension) and conductivity (on a 1:5 soil-deionized water suspension).

At Siena University, soil and moss samples were dried at $40^{\circ} \mathrm{C}$ to a constant weight. The unwashed mosses were carefully cleansed of all adhering soil, which was recovered for analytical determinations. Moss samples from subsites $C$ and $\mathrm{D}$ constituted three species. Moss subsamples from each subsite were analysed to determine the total content of $\mathrm{Ca}, \mathrm{Cu}$, $\mathrm{Fe}, \mathrm{K}, \mathrm{Mg}, \mathrm{Mn}, \mathrm{Na}$, and $\mathrm{Zn}$. These elements were also determined in the $<2 \mathrm{~mm}$ fraction of adhering, surface and subsurface soil samples, as well as in moss subsamples rinsed with water (1:5 w/v in a shaker for 2 hours). Samples of washed and unwashed moss and soil $(150 \mathrm{mg})$ were mineralized in clean Teflon vessels under pressure with $3 \mathrm{ml}$ of concentrated $\mathrm{HNO}_{3}$ (Merck Suprapur) at $120^{\circ} \mathrm{C}$ for 8 hours. Digested solutions were analysed by atomic absorption spectrophotometry using an oxyacetylene flame (FAAS) or graphite furnace with a Zeeman background correction (ZETAAS). Several elements (e.g. $\mathrm{Ca}, \mathrm{Cu}, \mathrm{Fe}, \mathrm{Mn}$ and $\mathrm{Zn}$ ) were also analysed in the same solution by Inductively Coupled Plasma Atomic Emission Spectrometry (ICP-AES). Element concentrations were determined by standard additions which were prepared by serial dilutions from $1 \mathrm{gl}^{-1}$ stock standards. 
Concentrations were expressed as percentage dry weight for $\mathrm{Fe}, \mathrm{Na}, \mathrm{K}, \mathrm{Ca}$ and $\mathrm{Mg}$, and as $\mu \mathrm{g} \mathrm{g}^{-1}$ on dry weight basis for the other elements. Data quality was checked by analysis of numerous blanks and Standard Reference Materials No. 1572 "citrus leaves" and No. 2711 "Montana soil" from the National Institute of Standards and Technology (NIST, Gaithersburg, USA) in each batch of samples. Sample batches differing by more than the standard deviation from the certified value were repeated. The recovery rate ranged between 92 and $105 \%$. Five replicates of several samples were analysed and the coefficients of variation ranged from $6.4-18.9 \%$ (depending on the element) in mosses, and from $4.1-16.3 \%$ in soil samples.

Major soluble cations $\left(\mathrm{Na}^{+}, \mathrm{K}^{+}, \mathrm{Ca}^{2+}, \mathrm{Mg}^{2+}\right)$ in the melted snow, stream and pond water samples were determined by FAAS and ICP-AES, and 1:5 w/v moss- and soil-water extracts (previously filtered through a $0.45 \mu \mathrm{m}$ cellulose acetate membrane). Major anions $\left(\mathrm{Cl}^{-}, \mathrm{SO}_{4}{ }^{2-}, \mathrm{NO}_{3}{ }^{-}\right.$and $\left.\mathrm{PO}_{4}{ }_{4}{ }^{3-}\right)$ were determined by ion chromatography. An IC-Pack Anion ${ }^{\mathrm{TM}}$ column $(0.46 \times 5.0 \mathrm{~cm}, 10 \mu \mathrm{m}$ particle size $)$ was used for anion separation. The eluent was a mixture of $1.46 \mathrm{mM}$ sodium gluconate, $5.82 \mathrm{mM}$ boric acid, $1.31 \mathrm{mM}$ sodium tetraborate. $10 \mathrm{H}_{2} \mathrm{O}, 34.2 \mathrm{mM}$ glycerine, $2.28 \mathrm{M}$ acetonitrile, and $0.22 \mathrm{M}$ n-butanol. All anions were separated at a flow rate of $1.2 \mathrm{ml}$ $\min ^{-1}$ within $12 \mathrm{~min}$. A Waters 432 conductivity detector was used at a cell temperature of $35^{\circ} \mathrm{C}$. Sample sizes up to $200 \mu \mathrm{l}$ were injected with a U6K manual injector. Anions were identified and quantified through standards prepared from $1000 \mathrm{mg} \mathrm{l}^{-1}$ stock solutions of each anion, using reagent-grade chemicals and Milli-Q water. $\mathrm{Na}^{+}$and $\mathrm{K}^{+}$, salts used to prepare the stock solutions, were dried at $80^{\circ} \mathrm{C}$ overnight. All standards and stock solutions were kept for no more than a month in plastic containers which were acid washed, rinsed and soaked with Milli-Q water for at least 24 hours. The accuracy of ion determinations was verified by routine determinations of ions in SRM no. 2694 «simulated rainwater» from the NIST (Gaithersburg, USA).

Summary statistics were used to calculate mean and standard deviations, and the Mann-Whitney $U$ test was used to test differences between groups at probability levels $<0.05$. All statistical computations were performed using the software program Statistica (StatSoft Inc.).

\section{Results}

\section{Field laboratory measurements}

Between 11 December and 5 February the air temperature at $50 \mathrm{~cm}$ above the ground ranged from -6.6 to $8.4^{\circ} \mathrm{C}$. Snowfall was very infrequent, with about ten brief events of snow flurries occurring during the study period; the snow rapidly sublimated, leaving the ground dry. One snowfall at the end of January covered the ground for about two days.

Table I summarizes the results of physical and chemical determinations on the surface and subsurface soil samples collected in December 1995 and January 1996. Soil particle size was dominated by gravels and coarse sand, with fine fractions (mainly accumulated in the deeper horizons) making up the remainder. The clay and silt fine fractions were negligible in almost all samples, except in the deepest horizons of subsites C and D, which were submerged until the end of December. Along the transect, water content increased from the ahumic soil (subsite A) to subsite D and in each subsite it increased with soil depth. Electrical conductivity was always higher in drier surface soils, and particularly in samples collected in January from subsite B. The $\mathrm{pH}$ values were

Table I. Physical and chemical parameters of soil at both sampling dates.

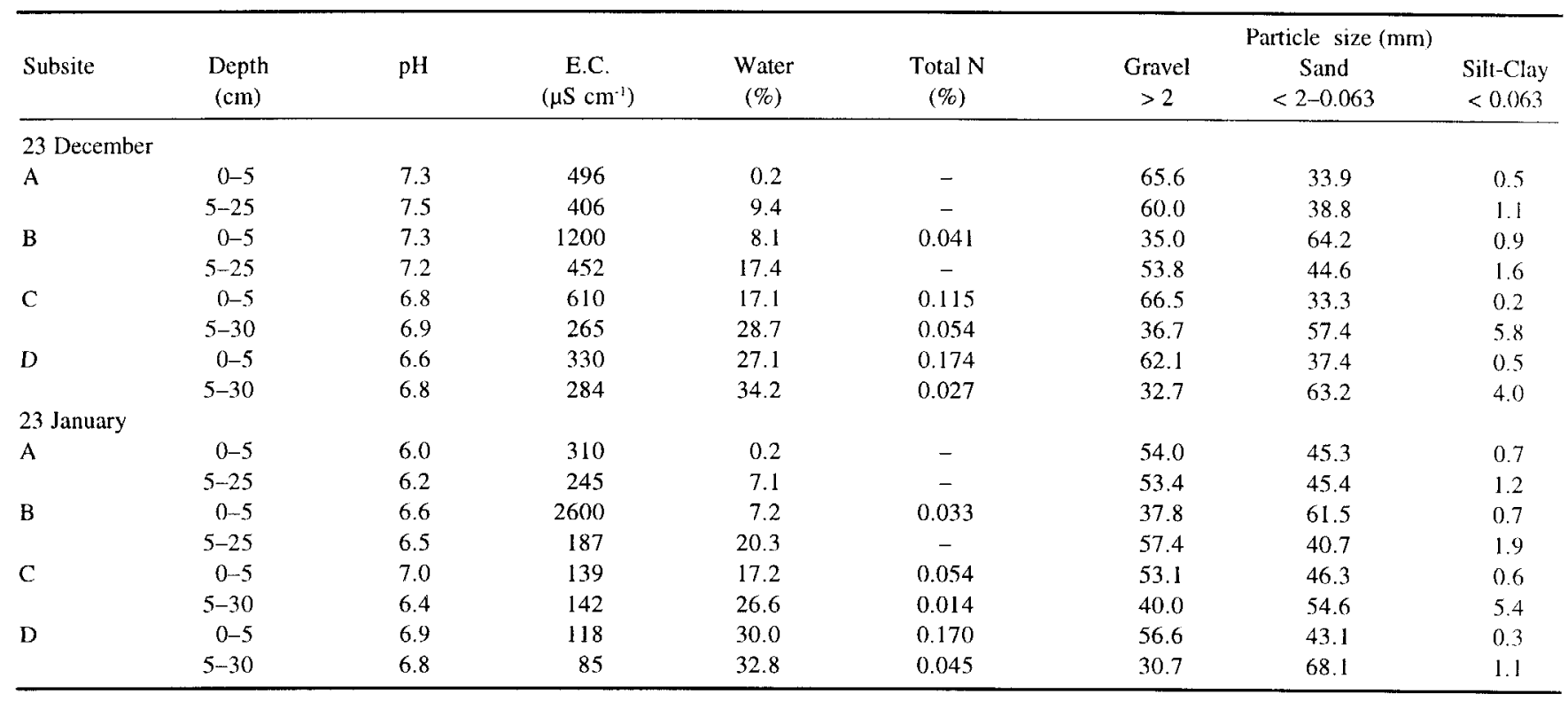

\footnotetext{
- Values below detection limits.
} 
almost neutral in December, whereas in January they declined slightly in the driest subsites.

\section{Concentrations of major ions in melt waters}

The mean $( \pm \mathrm{s} d)$ temperature $(\mathrm{T}), \mathrm{pH}$ and $\mathrm{EC}$ values measured in the stream flowing close to subsite $\mathrm{D}$ ( 23 December) were $4.7 \pm 1.1^{\circ} \mathrm{C}, 8.2 \pm 0.3$ and $240 \pm 46 \mu \mathrm{S} \mathrm{cm}{ }^{-1}$, respectively. Higher values were recorded in the pond, about $150 \mathrm{~m}$ to the east of the study site $\left(\mathrm{T}=9.3 \pm 0.8^{\circ} \mathrm{C} ; \mathrm{pH}=9.8 \pm 0.6 ; \mathrm{EC}=\right.$ $\left.313 \pm 23 \mu \mathrm{S} \mathrm{cm}^{-1}\right)$. Average values of the $\mathrm{pH}$ and $\mathrm{EC}$ of five subsamples of melted snow measured in the laboratory tent were $7.9 \pm 0.3$ and $83 \pm 16 \mu \mathrm{S} \mathrm{cm}^{-1}$, respectively. According to the distribution of EC values, total dissolved salts (calculated by summation of individual ion mass contribution) increased from $1.4 \mathrm{mg} \mathrm{l}^{-1}$ in melted snow to 88.8 and $95.1 \mathrm{mg} \mathrm{l}^{-1}$ in stream and pond water, respectively.

Figure 2 shows average concentrations of major ions in snow and water samples from the stream and pond, and 1:5 soil-water extracts from surface soil samples collected at the dry ahumic subsite (A). The global average chemical composition of sea water (SW) and fresh water (FW) is also given (Fergussen 1990). All samples showed very high concentrations of $\mathrm{Na}^{+}$and $\mathrm{Cl}^{-}$(about one order of magnitude higher than other ions). The relative ion abundance in stream and pond water and 1:5 soil-water extracts reflected the SW composition rather than that of $\mathrm{FW}$. The principal difference was the much lower $\mathrm{Ca}^{2+}$ and $\mathrm{Mg}^{2+}$ in soil-water extracts. Although water samples from the pond and the stream had essentially similar ionic composition, the concentration of $\mathrm{NO}_{3}^{-}$in the stream water was $25.8 \pm 3.1 \mu \mathrm{mol} \mathrm{l}^{-1}$ but was undetectable in pond water and melted snow.

\section{Elemental composition of moss and soil}

Figure 3 summarizes average concentrations of major and trace elements in washed and unwashed mosses, and the elemental composition of soil particles adhering to the moss at subsites B, C and D. Both soil and moss samples from the driest subsite (B) always had the highest content of major and trace elements. Concentrations of $\mathrm{Ca}, \mathrm{Mg}$ and $\mathrm{Na}$ in unwashed cushions of $H$. heimii were higher than those in the adhering soil, in both sampling periods. In the wetter subsites (C, D), mixed samples of $B$. argenteum, $B$. pseudotriquetrum and $C$. purpureus, especially in the unwashed moss, accumulated Ca to much higher levels than the underlying soil. In January, unwashed mosses from all subsites had higher $\mathrm{Na}$ concentrations. In general, the elemental concentration of the moss was increased by the adhering soil particles, and there were slight temporal variations, but without a consistent pattern.

In both sampling periods, washing removed about $40 \%$ of almost all elements. A much higher percentage (about 60 $80 \%$ ) of $\mathrm{Na}$ and $\mathrm{Cu}$ dissolved from dry cushions of $H$. heimii than from mosses in the wettest subsite. Total concentrations of $\mathrm{Mn}$ and $\mathrm{Zn}$ were scarcely affected by washing. Washed mosses from the wetter sites showed an increase of almost all elements from December to January.

As element concentrations measured in samples of surface and deep soil from subsites A, C and D did not show evident variations from December to January, mean values are illustrated in Fig. 4. Levels of $\mathrm{Ca}, \mathrm{Cu}, \mathrm{K}, \mathrm{Mg}$, and $\mathrm{Na}$ in surface soils progressively decreased (by up to a factor of 6 or 7 ) from the driest (A) to the wettest subsite (D). In the deeper horizons this decrease was only two-fold. Significant $(P<0.05)$ MannWhitney $U$ test variations in element concentrations between

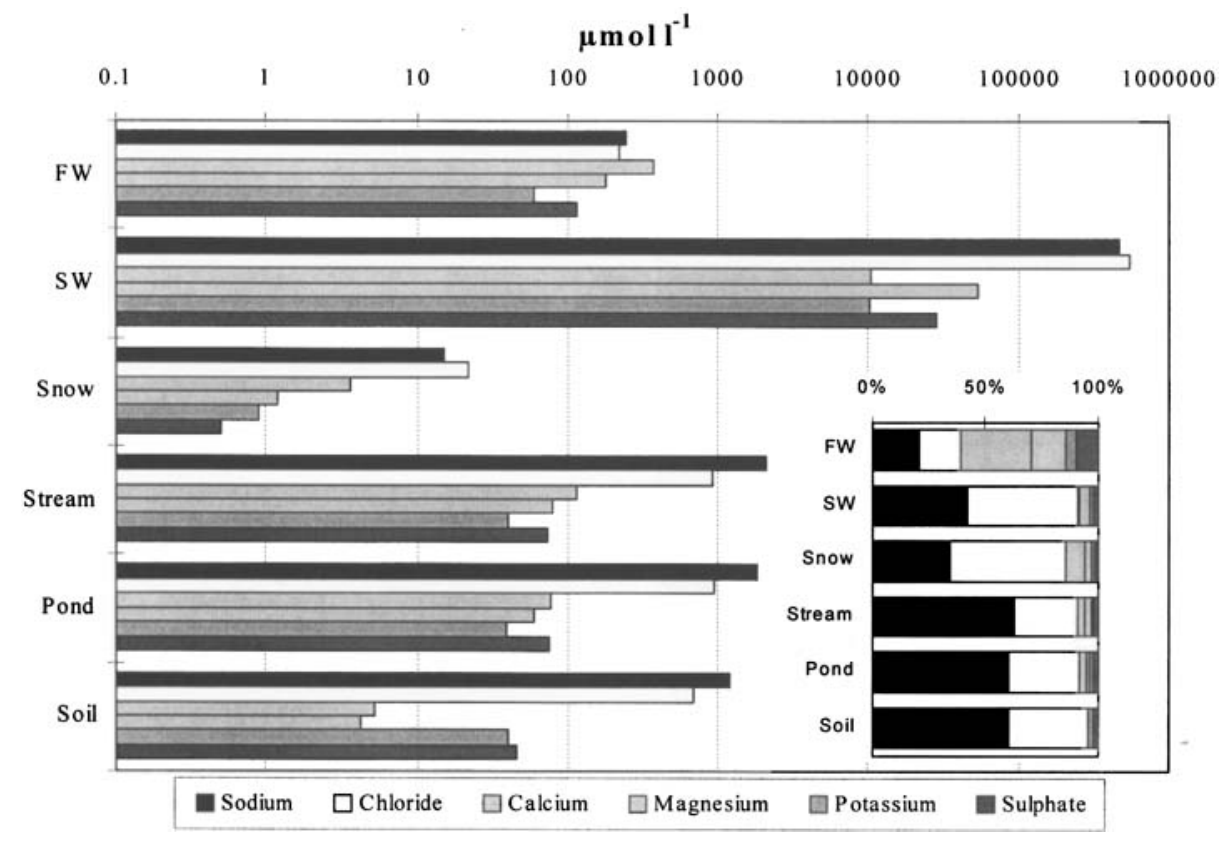

Fig. 2. Total and relative concentrations of major ions in samples of snow, stream- and pond- water, and in 1:5 soil-water extracts (soil surface, subsite A), compared with the average world freshwater (FW) and seawater (SW) composition. 

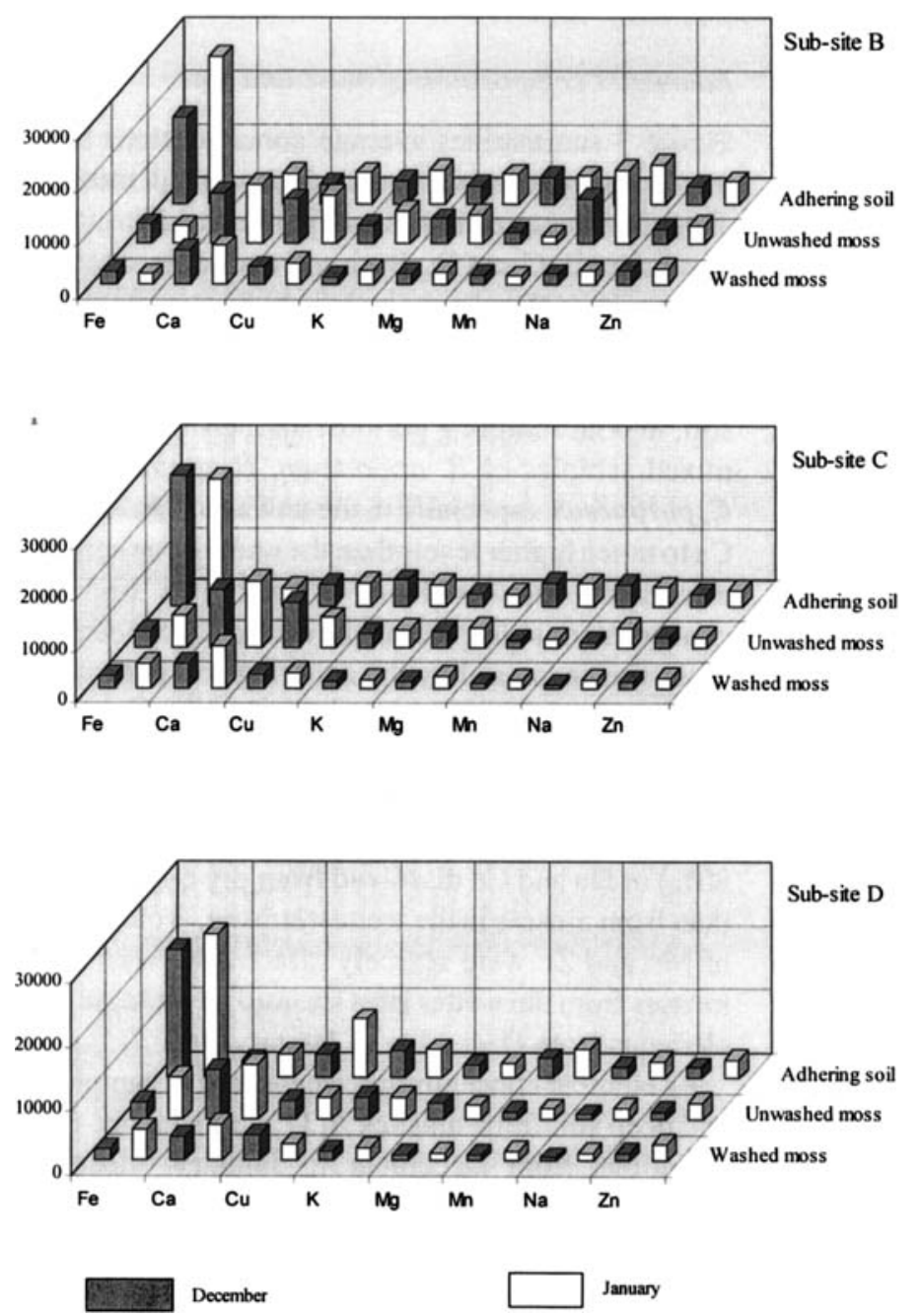

Fig. 3. Total concentrations $\left(\mu \mathrm{g} \mathrm{g}^{-1}\right.$, d.w.) of major and trace elements in washed and unwashed moss, and in the adhering soil from the vegetated sites, in December and January (for a suitable representation, concentrations of $\mathrm{Cu}, \mathrm{Zn}$ are multiplied by 100 , and by 10 for those of $\mathrm{Mn}$ ). surface and deep soil collected in December and January were detected in samples from subsite B (Fig. 5). In January, concentrations of $\mathrm{Ca}, \mathrm{Cu}, \mathrm{K}, \mathrm{Mg}$ and $\mathrm{Na}$ had decreased more than $50 \%$ in the deeper layer. However, these elements showed a slight increase in surface soils and in particles adhering to mosses.

The organic content in both ahumic and protoranker soils was generally very low and decreased from December 10

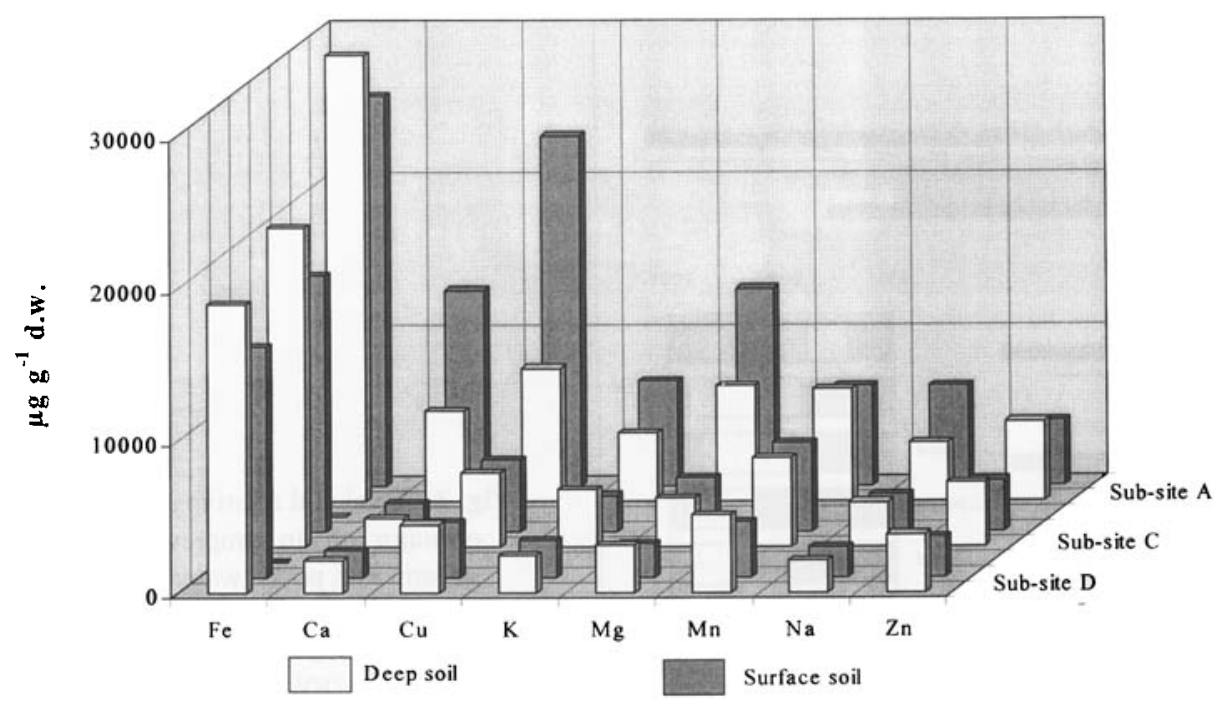

Fig. 4. Average concentrations $\left(\mu \mathrm{g} \mathrm{g}^{-1}\right.$, d.w.) of major and trace elements during summer in the soil surface $(0-5 \mathrm{~cm})$ and deep layers $(5-30 \mathrm{~cm}$; subsites $\mathrm{A}, \mathrm{C}$, D). Values for $\mathrm{Cu}, \mathrm{Zn}$ and $\mathrm{Mn}$ are exaggerated as in Fig. 3. 


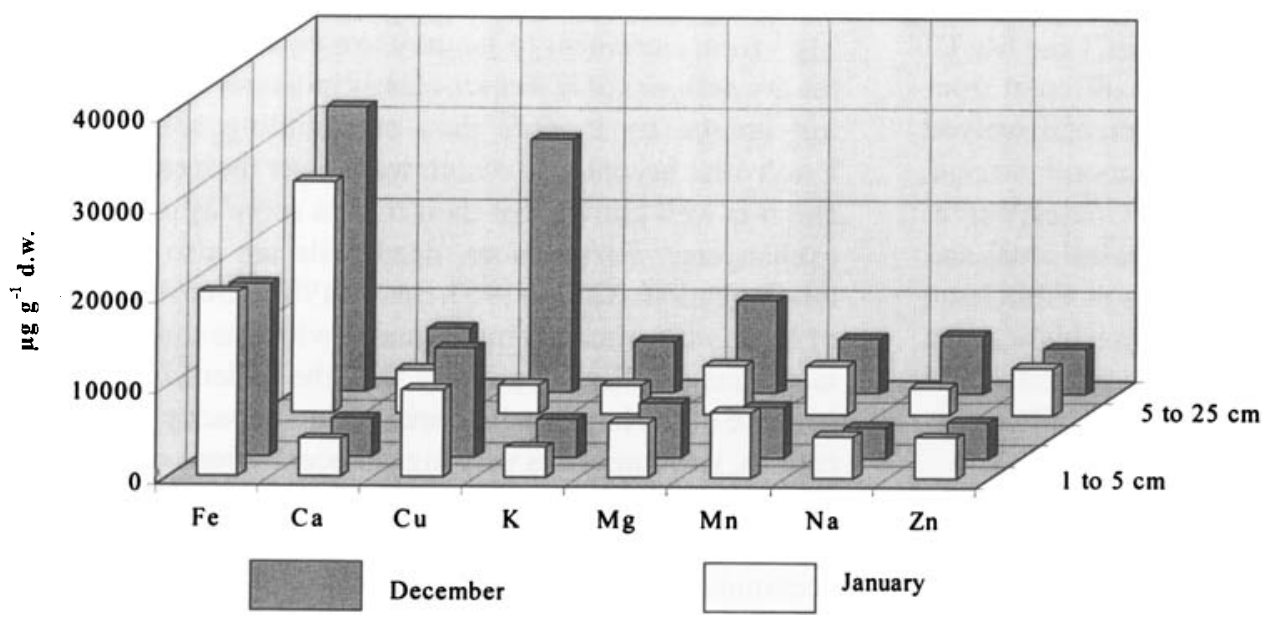

Fig. 5. Average concentrations $\left(\mu \mathrm{g} \mathrm{g}^{-1}\right.$, d.w.) in December and January of major and trace elements in the $1-5$ and $5-25 \mathrm{~cm}$ soil layers at subsite $\mathbf{B}$.
January. Values of TOC in deeper layers were always lower by a factor of two or three than those measured in surface soil (Fig. 6). Total $\mathrm{N}$ was detected mainly in surface layers of protoranker soil (Table I) and the $\mathrm{C} / \mathrm{N}$ ratio ranged from 3.99.0 .

\section{Water-extractable ions}

Table II summarizes the results of analytical determinations in water extracts $(1: 5 \mathrm{w} / \mathrm{v})$ from mosses and the $<2 \mathrm{~mm}$ fraction of soil samples. Levels of water soluble anions and cations in mosses and soils (both adhering to and beneath the moss turf) increased from the wettest to the driest site, and from December to January, with the highest values recorded for subsite B. Although this temporal increase was particularly evident in dry cushions of $H$. heimii (subsite $\mathrm{B}$ ), the mosses always released a quantity of ions one or two orders of magnitude higher than soils, irrespective of sampling site.

$\mathrm{NO}_{3}^{-}$was detected in moss-water extracts collected in January and values decreased sharply from the driest to the wettest sites. Conversely, $\mathrm{PO}_{4}^{3-}$ was primarily found in mosses from the wettest sites, and adhering soils, collected in December.

\section{Discussion}

In accordance with previous studies on water geochemistry of Antarctic coastal environments (Keys \& Williams 1981, Green et al. 1988, Piccardi et al. 1989, Cremisini et al. 1990, Gore et al. 1996), major ions in snow, melt water and soilwater extracts at Edmonson Point were predominantly marine in origin. Considering the proximity of the study area to the sea (about $400 \mathrm{~m}$ ), the deposition of salts may occur through marine aerosols, particularly during summer storms, and snow

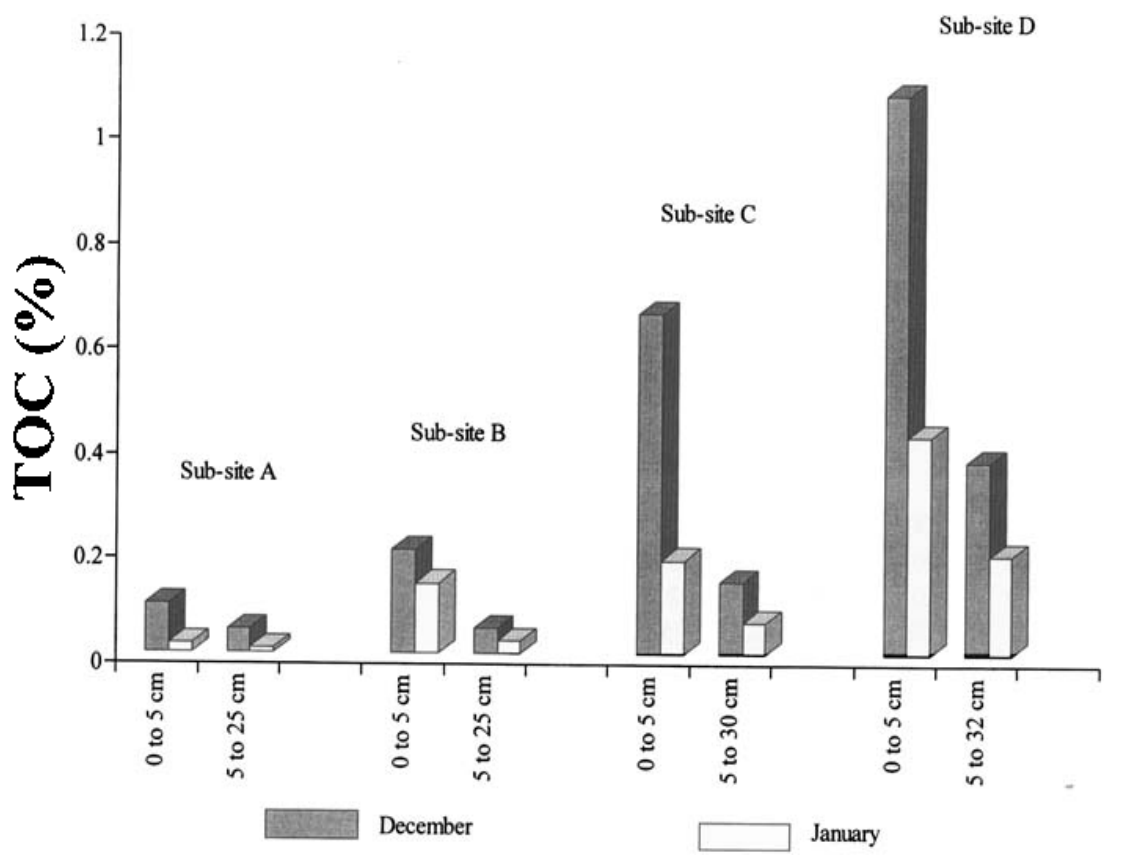

Fig. 6. Content of total organic carbon in surface and deep soil layer from the four sampling sites in the two sampling periods. 
blown off the sea ice. However, values of $\mathrm{Na} / \mathrm{Cl}$ and $\mathrm{Mg} / \mathrm{Cl}$ molar ratios in stream and pond waters were different from those of seawater, also indicating a contribution of dissolved salts from the substratum. According to geomorphological and sedimentological evidence, supported by ${ }^{14} \mathrm{C}$ dates (Baroni \& Orombelli 1994), on the deglaciation of coastal areas and the formation of modern and raised beaches at Edmonson Point, our study valley was at an elevation much higher than that observed for the highest berms. Thus, the solubilization by melt water of sea salts trapped by isostatic uplift seems unlikely.

Gibbs (1970) classified world surface waters according to whether their chemical composition is controlled by atmospheric inputs, interactions with rocks in the drainage basin or evaporation-crystallisation processes. The Na-rich and high-salinity waters at Edmonson Point fell outside the envelope of world waters depicted by Gibbs and occupy an intermediate position between those controlled by atmospheric precipitation and evaporation.

The presence of salt encrustations and entrapped soil particles make the assessment of element concentrations in Antarctic moss tissues very difficult. However, when the elemental composition of unwashed mosses from Antarctica is compared with that of other moss species from moist environments in the Northern Hemisphere (Wiersma et al. 1986, Steinnes et al. 1992), our data indicate very high concentrations of $\mathrm{Na}^{+}$and $\mathrm{Cl}^{-}$(a very high concentration of $\mathrm{Cl}^{-}$in unwashed moss can be inferred from data on moss-water extracts; Table II). Although values in washed samples should roughly reflect intracellular concentrations (i.e. the nutritional demand of mosses) it is well known that monovalent cations may occur in a soluble form within the moss cell (Bell 1959, Brown \& Bates 1990).

The large increase of extractable $\mathrm{Na}^{+}, \mathrm{Cl}, \mathrm{Ca}^{2+}, \mathrm{Cu}^{2+}$ and
$\mathrm{Mg}^{2+}$ from December to January in mosses, and especially in the dry cushions of $H$. heimii, clearly indicates a more efficient ion uptake by mosses than surrounding soil particles. Ectohydric bryophytes absorb water over their entire surface and it is well known that their tissues serve as powerful ion exchangers. Furthermore, dead cells are also capable of binding cations (Clymo 1963, Brown 1982). Because cushions of $H$. heimii are heavily impregnated with fine soil, the colony maintains capillary continuity with the underlying soil and, because of the large surface area and its capacity for binding cations, it accumulates very high concentrations of major and trace elements. Although salt precipitation derived from sublimation of surface snow may also contribute, the element accumulation in $H$. heimii seems to explain the decrease of total $\mathrm{Ca}, \mathrm{Cu}, \mathrm{K}, \mathrm{Mg}$ and $\mathrm{Na}$ concentrations in the deeper soil horizons of subsite $B$.

According to previous reports (Cameron 1972; Ugolini \& Anderson 1973, Ugolini 1977), not only do dry cushions of $H$. heimii seem to enhance the upward migration of salt solutions, but the moss is also able to maintain a higher moisture content than the adjacent surface ahumic soil throughout the summer. Ahumic soils have very low concentrations of TOC and, as previously reported by Campbell $\&$ Claridge (1987), $\mathrm{pH}$ values are related to those of the chloride/sulphate ratio $\left(\mathrm{pH}>7\right.$ and $\mathrm{Cl} / \mathrm{SO}_{4}{ }^{2-}=15.1$ in December; $\mathrm{pH}<6.2$ and $\mathrm{Cl} / \mathrm{SO}_{4}{ }^{2-}=6.0$ in January). Conversely, protoranker soils had a relatively high content of organic matter which improved the buffering capacity of the soil, water retention and generally determined more favourable ecological conditions for alga and invertebrate colonization. Furthermore, the lower $\mathrm{C} / \mathrm{N}$ ratio values found in protoranker soils compared to those usually reported for mosses, the fluctuations of the organic carbon content during the growing

Table II. Mean concentration ( $\mu \mathrm{mol} \mathrm{I}^{-1}$ ) of major ions measured in 1:5 soil- and moss-water extracts from samples collected in December 1995 and January 1996 (in parenthesis).

\begin{tabular}{|c|c|c|c|c|c|c|c|c|c|c|c|c|c|c|c|c|c|}
\hline \multirow{3}{*}{$-\frac{\text { Site }}{\mathrm{A}}$} & \multirow{2}{*}{$\begin{array}{c}\text { Depth } \\
(\mathrm{cm})\end{array}$} & \multicolumn{2}{|c|}{$\mathrm{Na}^{+}$} & \multicolumn{2}{|r|}{$\mathrm{K}^{+}$} & \multicolumn{2}{|c|}{$\mathrm{Ca}^{2+}$} & \multicolumn{2}{|c|}{$\mathrm{Mg}^{2+}$} & \multicolumn{2}{|c|}{$\mathrm{Cl}^{-}$} & \multicolumn{2}{|c|}{$\mathrm{SO}_{4}^{2-}$} & \multicolumn{2}{|c|}{$\mathrm{NO}_{3}$} & \multicolumn{2}{|c|}{$\mathrm{PO}_{4}^{3}$} \\
\hline & & 1191 & $(1023)$ & 40 & (47) & 5.0 & (5.4) & 4.0 & $(2.5)$ & 696 & $(572)$ & 46 & $(58)$ & 16 & $(29)$ & 5.2 & $(-)$ \\
\hline & $5-25$ & 395 & $(571)$ & 10 & (19) & 5.4 & $(8.7)$ & 1.6 & (7.8) & 490 & (332) & 17 & (39) & 10 & (20) & 5.6 & $(-)$ \\
\hline \multirow[t]{4}{*}{$\mathrm{B}$} & moss & 193000 & $(210000)$ & 8000 & $(16700)$ & 8100 & $(17500)$ & 12900 & $(20300)$ & 194000 & $(367000)$ & 10700 & (12500) & 2650 & $(12600)$ & ) - & $(-)$ \\
\hline & adhering soil & 17600 & $(28200)$ & 700 & $(1400)$ & 600 & $(2100)$ & 1100 & $(1400)$ & 17200 & $(21900)$ & 1600 & $(2100)$ & 1024 & $(785)$ & - & $(-)$ \\
\hline & $0-5$ & 8197 & $(9016)$ & 375 & $(473)$ & 592 & $(1000)$ & 505 & $(718)$ & 7374 & (11521) & 559 & $(413)$ & 258 & (449) & - & $(-)$ \\
\hline & $5-25$ & 471 & $(172)$ & 40 & $(9.5)$ & 50 & $(7.5)$ & 40 & $(2.5)$ & 1907 & $(155)$ & 45 & (14) & 30 & $(7.1)$ & - & $(-)$ \\
\hline \multirow[t]{4}{*}{$\mathrm{C}$} & moss & 4300 & $(31600)$ & 4800 & $(4500)$ & 3400 & $(2500)$ & 3400 & $(3000)$ & 21000 & $(23800)$ & 1800 & $(1500)$ & - & $(2600)$ & 1458 & (880) \\
\hline & adhering soil & 4000 & $(2700)$ & 300 & $(300)$ & 200 & $(100)$ & 100 & $(100)$ & 5900 & $(2500)$ & 100 & $(100)$ & - & $(85)$ & 230 & $(100)$ \\
\hline & $0-5$ & 1603 & (643) & 170 & (54) & 160 & $(43)$ & 130 & $(37)$ & 2183 & $(436)$ & 163 & (49) & 7 & $(9.6)$ & 19 & (18) \\
\hline & $5-30$ & 317 & $(244)$ & 20 & $(6.3)$ & 7.5 & $(4.2)$ & 7.5 & $(2.2)$ & 522 & (76) & 21 & $(8.8)$ & 15 & $(7.7)$ & 11 & (5.4) \\
\hline \multirow[t]{4}{*}{$\mathrm{D}$} & moss & 2300 & $(9500)$ & 5200 & $(4300)$ & 2200 & $(1600)$ & 1900 & $(1300)$ & 4300 & $(38100)$ & 900 & $(400)$ & - & $(670)$ & 2187 & $(130)$ \\
\hline & adhering soil & 2100 & $(1300)$ & 300 & $(400)$ & 100 & (70) & 100 & $(40)$ & 600 & $(700)$ & 20 & (40) & - & $(465)$ & 565 & $(400)$ \\
\hline & $0-5$ & 661 & (571) & 90 & (64) & 35 & (19) & 15 & (10) & 290 & (189) & 50 & (28) & 36 & (73) & 22 & $(-)$ \\
\hline & $5-30$ & 281 & (317) & 15 & (12) & 12 & $(5.7)$ & 1.2 & (2.4) & 116 & $(120)$ & 14 & (14) & 24 & $(10)$ & 2.1 & $(-)$ \\
\hline
\end{tabular}

- Values below detection limits. 
season, as well as the presence of terrestrial invertebrate and fungal communities (Bargagli et al. 1996, Fenice et al. 1997) probably indicated the occurrence of nutrient cycling.

In December $\mathrm{NO}_{3}^{-}$was found mainly in the stream water, which might indicate nitrification and leaching from mosses and the protoranker soil in the wettest subsites. Furthermore, soil adjacent to the stream was dominated by cyanobacteria, especially Nostoc commune, which are capable of fixing atmospheric nitrogen. In January, when all subsites were drier, the highest concentrations of $\mathrm{NO}_{3}^{-}$were detected in dry moss and protoranker soil at subsite $\mathrm{B}$, which was barely affected by the flowing of water during the summer. Indeed, cyanobacteria may play an important role in the nitrogen dynamics of moist moss communities. Davey \& Marchant (1983) and Davey (1986) demonstrated that Antarctic Nostoc commune is capable of fixing relatively large amounts of atmospheric nitrogen during periods of high insolation when surface temperatures exceed $8^{\circ} \mathrm{C}$ and the substratum is moist, and that a small amount of fixation can continue down to $-7^{\circ} \mathrm{C}$. At this site Smith (in press) has shown that favourable conditions can therefore exist for diel nitrogen fixation for much of the short summer. By contrast, $\mathrm{PO}_{4}{ }^{3-}$ was detected in December in wetter sites. In southern Victoria Land streams are not ultraoligotrophic but have relatively high nutrient levels associated with early melt. This initial pulse was interpreted as promoting stream flora which quickly resume metabolic activity on rehydration (Vincent \& Howard-Williams 1986, HowardWilliams et al. 1997).

\section{Conclusions}

Water availability is the main factor controlling moss colonization in terrestrial Antarctic ecosystems (Kennedy 1993), although substratum stability is crucial for the persistence of colonists and community development. Analysis of snow and running waters showed that the biogeochemistry of major elements in the Edmonson Point coastal environment is largely affected by marine ions. At the surface of coarse textured and dark coloured soils, the sublimation of snow and water evaporation created a steep moisture gradient along the soil profile and the deposition of encrusting salts at the surface. Soils covered by mosses were wetter and accumulated more organic matter than neighbouring ahumic soils. Moreover, in these soils there was evidence of better buffering capacity and of carbon and nitrogen cycling. A high proportion of surface salt encrustation occurred on dry mosses, probably because of their higher moisture content, large evaporation surface and the high cation exchange capacity. Cushions of $H$. heimii in the driest zones bound cations more efficiently than adhering soil particles. Conversely, mosses in the wettest central part of the depression were still moist at the end of the summer and were less affected by surface salt deposition. Throughout the summer moss tissue accumulated $\mathrm{Ca}$ and other essential macro- and trace elements such as $\mathrm{Fe}, \mathrm{Mg}, \mathrm{Na}$ and $\mathrm{Zn}$.
When the elemental composition of unwashed samples of different species of Antarctic moss is compared with that of samples from the Northern Hemisphere, the most striking differences are the large amount of trapped soil particles and the considerable accumulation of water-extractable $\mathrm{Na}^{+}$and $\mathrm{Cl}$. These, and other elements, probably occur as precipitates on the moss surface and do not interfere with their metabolism. However, further research is necessary to establish the proportion of elements accumulated in moss tissues, and those adsorbed onto their surface, and whether salt deposition is caused by passive physical forces maintained by water evaporation from exposed surfaces, the sublimation of snow or active exudation mechanisms within the moss.

\section{Acknowledgements}

This research was supported by funds of the PNRA (Programma Nazionale di Ricerca in Antartide), which made possible the BIOTEX 1 Expedition. We wish to thank everyone who participated in the expedition. We would also like to thank Dr P. Selkirk and two anonymous referees for valuable comments.

\section{References}

Bargagli, R., Wynn-Williams, D., Bersan, F., Cavacini, P., Ertz, S., Frati, F., Freckman, D., Smuth, R.I.L., Russell, N. \& Smith, A. 1996. Field Report. BIOTEX 1: first BIOTAS expedition (Edmonson Point-Baia Terra Nova, Dec 10 1995-Feb 6 1996). Newsletter of the Italian Biological Research in Antarctica, 1, 42-58.

Baroni, C. \& Orombelli, G. 1994. Holocene glacier variations in the Terra Nova Bay area (Victoria Land, Antarctica). Antarctic Science, 6, 497-505.

Bell, P.R. 1959. The ability of Sphagnum to absorb cations preferentially from dilute solutions resembling natural waters. Journal of Ecology, 47, 351-355.

Brown, D.H. 1982. Mineral nutrition. In Smith, A.J.E., ed. Bryophyte ecology. London: Chapman \& Hall, 383-444.

Brown, D.H. \& Bates, J.W. 1990. Bryophytes and nutrient cycling. Botanical Journal of the Linnean Society, 104, 129-147.

Cameron, R.E. 1972. Microbiological and ecologic investigations in Victoria Valley, Southern Victoria Land. Antarctic Research Series, 20, 195-260.

Cameron, R.E., King, J. \& David, C.N. 1970. Soil microbial ecology of Wheeler Valley, Antarctica. Soil Science, 109, 110-120.

Campbell, I.B. \& Claridge, G.G.C. 1987. Antarctica: soils, weathering processes andenvironment. Amsterdam: Elsevier Science Publishers, $368 \mathrm{pp}$.

Claridge, G.G.C. \& Campbell, I.B. 1977. The salts in Antarctic soils, their distribution and relationship to soil processes. Soil Science, 123, 377-384.

Claridge, G.G.C., Campbell, I.B. \& Balks, M.R. 1997. Ionic migration in soils of the Dry Valley region. In Lyons, W.B., Howard-WILliams, C. \& Hawes, 1., eds. Ecosystem processes in Antarctic ice-free landscapes. Rotterdam: Balkema, 137-143.

Clymo, R.S. 1963. Ion exchange in Sphagnum and its relation to bog ecology. Annals of Botany, 27, 309-324.

Convey, P. \& Marshall, W. 1997. Dispersal of moss propagules on Signy Island, maritime Antarctic. Polar Biology, 18, 376-383. 
Cremisin, C. Orlando, C. \& Torcini, S. 1990. Major, minor and trace elements in surface waters at Terra Nova Bay. A review of obtained data from 1986 to 1989 Italian Antarctic Expeditions. Meeting on environmental impact in Antarctica, Rome. Abstract, 7-16.

De Mora, S.J., Whitehead, R.F. \& Gregory, M. 1991. Aqueous geochemistry of major constituents in the Alph River and tributaries in Walcott Bay, Victoria Land, Antarctica. Antarctic Science, 3, $73-86$.

DAVEY, A. 1986. Nitrogen fixation by cyanobacteria in the Vestfold Hills. In PICKARD, J., ed. Antarctic oasis: terrestrial environments and history of the Vestfold Hills. Sydney: Academic Press, 203-220.

Davey, A. \& Marchant, H.J. 1983. Seasonal variation in nitrogen fixation by Nostoc commune Vaucher at the Vestfold Hills, Antarctica. Phycologia 22, 377-385.

Fenice, M., Selbmann, L., Zucconi, L. \& Onofri, S. 1997. Production of extracellular enzymes by Antarctic fungal strains. Polar Biology, 17, 275-280.

FERGUSSON, J.E. 1990. The heavy elements: chemistry, environmental impact and health effects. Oxford: Pergamon Press, 614 pp.

Gaudette, H.E., Flight, W.R., Toner, L. \& Folger, D.W. 1974. An inexpensive titration method for the determination of organic carbon in recent sediments. Journal of Sedimentary Petrology, 44, 249-253.

Gises, R.J. 1970. Mechanisms controlling world water chemistry. Science, 170, 1088-1090.

Gore, D.G., Crfagh, D.G., Burgess, J.S., Colhoun, E.A., Spate, A.P. \& BAIRD A.S. 1996. Composition, distribution and origin of surficial salts in the Vestfold Hills, East Antarctica. Antarctic Science, 8, 73-84.

GREEN, W.J., ANGLE, M.P. \& ChAVE, K.E. 1988. The geochemistry of Antarctic streams and their role in the evolution of four lakes of the McMurdo Dry Valleys. Geochimica Cosmochimica Acta, 52, 1265-1274.

Howard-Williams, C., Hawes, I., Schwarz, A.-M., Hall, J.A. 1997. Sources and sinks of nutrients in a polar desert stream, the Onyx River, Antarctica. In Lyons, W.B., Howard-Williams, C. \& Hawes, I., eds. Ecosystem processes in Antarctic ice-free landscapes. Rotterdam: Balkema, 155-170.

Kappen, L. \& Straka, H. 1988. Pollen and spores transport into the Antarctic. Polar Biology, 8, 173-180.

KENNEDY, A.D. 1993. Water as a limiting factor in the Antarctic terrestrial environment: a biogeographic synthesis. Arctic and Alpine Research, 25, 308-315.
KEYS, J.R. \& WiLLIAMS, K, 1981 . Origin of crystalline, cold desert salts in the McMurdo region, Antarctica. Geochimica Cosmochimica Acta, 45, 2299-2309.

KYLE, P.R. 1990. McMurdo volcanic group western Ross embayment Antarctic Research Series, 48, 19-488.

Linskens, H.F., Bargagli, R., Cresti, M. \& Focardi, S. 1993 Entrapment of long distance transported pollen grains by various moss species in coastal Victoria Land, Antarctica. Polar Biology. $13,81-87$.

Marshall, W.A. 1996. Biological particles over Antarctica. Nature 383,680 .

Piccardi, G., Udisti, R. \& Barbolani, E. 1989. Analysis of the principal components of Antaretic precipitations. Annali di Chimica. 79, 701-711.

Smith, R.I.L. 1984. Terrestrial plant biology of the sub-Antarctic and Antarctic. In Laws, R.M., ed. Antarctic ecology, vol 1, London: Academic Press, 61-162.

SMrth, R.1.L. 1991. Exotic sporomorpha as indicators of potential immigrant colonists in Antarctica. Grana, 30, 313-324.

SMITH, R.I.L. In press. Biological and environmental characteristics of three cosmopolitan mosses dominant in continental Antarctica. Journal of Vegetation Science.

Smith, R.I.L \& Wynn-Williams, D.D. 1992. Introduction to the BIOTAS Programme. In WYNN-WILlIAMS, D.D., ed. BIOTAS manual of methods. Cambridge: Scientific Committee on Antarctic Research, $1-12$.

Steinnes, E., Rambek, J.P. \& Hanssen, J.E. 1992. Large scale multielement survey of atmospheric deposition using naturally growing moss as biomonitors. Chemosphere, 25, 735-752.

Ugolin, F.C. \& ANDERson, D.M. 1973. Ionic migration and weathering in frozen Antarctic soils. Soil Science, 115, 461-470.

UGoLins, F.C. 1977. The protoranker soils and the evolution of an ecosystem at Kar Plateau, Antarctica. In Llano, G.A., ed. Adaptions within Antarctic ecosystems. Washington, DC: Smithsonian Institution, 1091-1110.

VINCENT, W. \& Howard-Williams, C. 1986. Antarctic stream ecosystems physiological ecology of a blue-green algal epilithion. Freshwater Biology, 16, 219-233.

Wiersma, G.B., Slaughter, C., Hilgert, J., McKee, A. \& Halpern, C. 1986. Reconnaisance of Noatak National Preserve and Biosphere Reserve as a potential site for inclusion in the integrated global background monitoring network. Springfield: US Department of Commerce, National Technical Information Service, $84 \mathrm{pp}$. 